\title{
Oceanography and Economics
}

$I_{r}$ During that time the magazine. and The Oceanography Society itself. have continued to evolve. albeit at geological rates.

Frankly. we are not exactly overworked. The manuscripts are not pouring in. We are in what Mr. Reagan would undoubtedly describe as a "trickle down" situation. But. unlike certain politicians. we are willing to change our views.

Originally we believed that material appearing in Oceanography should be primarily unsolicited. as occurs in most professional journals. An Adam-Smithian rule of the marketplace, if you will. However, the invisible hand of the market appears to be paralyzed. perhaps because people are not used to the idea of writing for a general audience. or (more likely) because most people want to spend a minimum amount of time writing papers and would prefer to invest that time in a focused approach to immediate peers. The TOS mutual fund seems to be less appealing than the high-yield utilities.

OK. let's try a different investment strategy. We will try to involve you. the producers and consumers. in planning topics for future issues. They could be single articles which you wish someone would write. or entire issues devoted to different views of a single topic. such as the "Iron Hypothesis" issue (Vol. 4. No. 2). We are already planning one on Marine Biodiversity. We'd also like to see more op-ed pieces. like the article by Gunther Krause and Matthias Tomczak in this issue.

The key to this effort will be the identification of topics and potential authors suggested by YOU. Because our field is so diverse and the authors so spread worldwide. we will rely on electronic communications. On the TOS home page (http://www.ccpo.odu.edu/tos_menu.html) you will find the plans for future issues as they develop. Please look over the tentative plans and contribute ideas or nominate authors. We believe this innovative way of involving the membership of TOS and the oceanographic community at large will lead to a better Oceanography.

-Larry Atkinson

Connie Sancetta

\section{WE'VE MOVED. . .}

TOS Headquarters has moved to a new office. You can now reach us at:

\author{
4052 Timber Ridge Drive \\ Virginia Beach. VA 23455 \\ USA \\ Phone: (804) 464-0131; FAX: (804) 464-1759; \\ Internet: jrhodes@ccpo.odu.edu
}

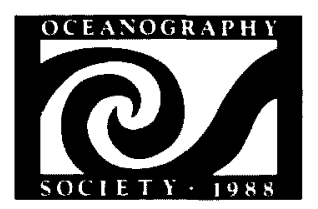

THE OCEANOGRAPHY SOCIETY

4052 Timber Ridge Drive Virginia Beach, VA 23455 USA (804) 464-0131: fax: (804) 464-1759

\section{OFFICERS}

Margaret Leinen. President Robert A. Duce. President-Elect Melbourne G. Briscoe. Secretary David Evans. Treasurer Arnold L. Gordon. Past-President

$$
\begin{gathered}
\text { COUNSELORS } \\
\text { Richard T. Barber } \\
\text { Stephen E. Calvert } \\
\text { Tommy D. Dickey } \\
\text { Robert F. Anderson } \\
\text { Rick Spinrad }
\end{gathered}
$$

EXECUTIVE DIRECTOR Judi Rhodes

CORPORATEINSTITUTIONAL SPONSORS Aanderaa Instruments. Inc. Wobum. MA. USA Chishitsu Chosa-Jo, Ibaraki, Japan GE Astro Space Division Princeton, NJ, USA John G. Shedd Aquarium, Chicago. IL, USA Monterey Bay Aquarium Research Institute. Pacific Grove. CA. USA

National Marine Fisheries Service. Silver Spring. MD. USA

Ober, Kaler, Grimes \& Shriver, Washington. DC. USA

AD Instruments, San Diego. CA. USA

Scripps Institution of Oceanography. La Jolla. CA. USA

Woods Hole Oceanographic Institution.

Woods Hole. MA. USA

\section{Oceanography}

CO-EDITORS Larry $P$. Atkinson

Center for Coastal Physical Oceanography Old Dominion University Crittenton Hall

Nortolk. VA 23529 (804) 683-5558 Internet: atkinson@ccpo.odu.edu Connie Sancetta National Science Foundation Ocean Sciences Division Room 725 4201 Wilson Blvd. Arlington, VA 22230 (703) 306-1586 Internet: csancett@nst.gov

ASSOCIATE EDITORS James $W$. Ammerman Department of Oceanography

Texas A\&M University College Station. TX 77843 USA (409) 845-5105

Gregg J. Brunskıll Australian Institute of Marine Science PMB No. 3. Townsville, M.C. Queensland 4810 . Australia (077) 789 211: FAX (077) 725852 ; Internet: g_brunskill 9 aims gov.au 